\title{
PRIVATE DIPLOMACY INITIATIVES AND INTERNATIONAL NETWORKS IN THE 1920s-1940s ROMANIA
}

\author{
Radu ALBU COMĂNESCU, PhD \\ Babeș-Bolyai University, Cluj-Napoca, Romania \\ radu.albu@ubbcluj.ro
}

\begin{abstract}
Based on private and official archives, the text focuses on the background, the diplomatic and paradiplomatic activity of three princely, intertwined Romanian families: Bibesco, SStirbey and Brancovan. Heirs to the throne of Wallachia before the arrival of the Hohenzollern monarchs in 1866, these families developed powerful diplomatic, economic and cultural networks in France, Belgium, Britain, Russia, Germany and AustriaHungary conferred influence at home and in various European circles. With solid foundations built since the 1850s, they helped shaping Romania's diplomacy in the first half of the $20^{\text {th }}$ century and contributed to the country's pro-European attitude of the 1920s-1930s. Evolving between European capitals and the US, on friendly terms with royalty, high-ranking politicians (Churchill, Roosevelt, Ramsay MacDonald, Léon Blum, Aristide Briand and various French presidents), diplomats and intellectuals (from Louise Weiss, Saint-John Perse, Duff Cooper and Paul Morand to Harold Nicolson, Paul Valéry and Wladimir d'Ormesson), industrialists and bankers, the three families promoted ideas or granted support to initiatives that anchored Romania in the West and enforced European cooperation. The text refers to the personal and professional profiles of prince Antoine Bibesco (d. 1951), of his wife, Elisabeth (née Asquith), of George III, Prince Bibesco (d. 1941), of MichaelConstantine (Bibesco) Prince Bassaraba de Brancovan (d. 1967), and last but not least, of Barbo, Prince Stirbey (d. 1946).
\end{abstract}

Keywords: Private Diplomacy, Cultural Diplomacy, Negotiations, International Relations, Interwar Europe

\section{Introduction. Historical outline and theoretical premises}

Dwelling on a topic already discussed in previous intervention ${ }^{26}$, the following text debates aspects from the public, diplomatic and paradiplomatic activity of three princely Romanian

\footnotetext{
${ }^{26}$ For the conference Sociabilités, réseaux et pratiques diplomatiques en Europe de 1919 à nos jours, organised by the Réseau International de Jeunes Chercheurs en Histoire de l'Intégration Européenne in partnership with the Royal Academy of Belgium, Brussels, March 20, 2015.
} 
families: Bibesco, Știrbey and Bassaraba de Brancovan ${ }^{27}$, developing it in the larger frame of a theoretical analysis which focuses on the role of private actors and their sociability praxis in diplomacy.

Sharing common origins (as descended from two brothers, George Bibesco and Barbo Bibesco Ştirbey, Princes-Sovereign of Wallachia from 1842 to 1856), the three families were descended on female line from the last branch of the founding dynasty of Wallachia, the Bassarab $^{28}$. A sophisticated and nuanced legal context allowed them to be considered heirs to Wallachia's throne before the 1866 election of the Hohenzollern-Sigmaringen dynasty. From this position, the three families developed - starting with the second half of the $19^{\text {th }}$ century - exclusive cultural, economic and political ties to France, Belgium, Great Britain but also Russia, AustriaHungary and Germany, in ways that reinforced their international standing and support for a potential return on Romania's throne. These connections also brought a certain influence in the circles of power of the aforementioned countries, emphasised by the family alliances.

George I Bibesco ( $\uparrow 1873)$, Prince-Sovereign of Wallachia until the 1848 Revolution, had been educated in France, where he would send his sons as well: Grégoire Bibesco Bassaraba de Brancovan, Nicholas, George II and Alexander, of which two (Nicholas and George II) will become officers of the French army during the Second Empire ${ }^{29}$. Aware of the political dimensions of their heritage - at a time of mobility within Europe's ruling families -, the two considered that the return on Romania's throne had to be achieved through and by the power of law. Diplomacy, international agreements and the support of Great Powers embodied therefore the only acceptable means; a family agreement concluded in 1873 between Grégoire de Brancovan, Nicholas and

\footnotetext{
${ }^{27}$ In Romanian: Bibescu, Ştirbey, Basarab-Brâncoveanu. A fairly old western Wallachian family - dating back to the 16th century -, emerging to political power in the second half of the 18th century and especially during the 19th century, the Bibescos gradually split into three main and three cadet branches.

${ }^{28}$ Following the marriage of George Bibesco (regn. 1842-1848) with Zoe Mavrocordato Bassaraba de Brancovan, their eldest son, Grégoire Bibesco (1827-1886), would receive from his legal grandfather, Prince Grigore Bassaraba de Brancovan (1764-1832) the right to bear his name and inherit the Brancovan princely titles, granted in 1695 by Holy Roman Emperor Leopold I of Austria to their forefather, Constantine de Brancovan, Wallachia's sovereign Prince from 1688 to 1714 .

29 The marriages of both were concluded in families related to Emperor Napoléon III: a daughter of the duke of Elchingen, prince of the Moskowa, for Nicholas Bibesco (her cousins, the Princes Murat, once royal family in the French Empire kingdom of Naples, were part of the civil family of the Emperor); and for George II a daughter of the Belgian Prince of Chimay (branch of the French family Riquet de Caraman de Chimay), cousin of Empress Eugénie. Prior to his Chimay union, George II Bibesco had been engaged to the Russian princess Vera Lobanov Rostovski, née Dolgoruki, cousin of Catherine, the second wife of Emperor Alexander II of Russia.
} 
George II Bibesco expressed their will to concert efforts in order to reach that specific goal (BAP, $2)^{30}$. Of them, George II Bibesco (1835-1902), French staff officer, corresponding member of Institut de France, was the one who added value to the family heritage, affixing dynastic legitimacy to a genuine political programme of Liberal-Conservative inspiration. Through his books, articles and public conferences, George II Bibesco shaped a political, economic and diplomatic alternative substantially different from what was practiced in Bucharest by King Carol I and the Liberal Party (Bibesco, 1894; 1888).

A fine observer of the international scene, he considered that only a national dynasty, wellconnected externally, with demonstrated abilities for good governance, should bear the Crown as a quintessence of the country's history, of its cultural and religious traditions, in a dynastic continuity which Bibesco opposed to the election of any foreign, unrepresentative ${ }^{\text {ruler31 }}$. In contrast with the positions embraced by the new Hohenzollern monarch and his Liberal partners, Bibesco advised a diminishment of the conflicts with Romania's neighbours, especially imperial Russia after 1878 and Austria-Hungary (on themes related to Danube policies), but also with the Great Powers. Bibesco was the advocate of a rapprochement with France and Great Britain policies that would position Romania in line with Europe's most advanced economies and societies, and a rational military alliance with Russia, Europe's largest military power (also a neighbour that could counterbalance Austrian-Hungarian pressure). He also proposed finding the grounds for a most equitable relation to Austria-Hungary, having in mind the Romanian Orthodox population from Transylvania, as well as with Prussia, as a balancing factor between Russia and the Austrian monarchy.

His ideas, lucidly and judiciously presented, proved realistic when the Franco-Russian alliance of 1892 was concluded, and even more in the next decade when the Franco-RussianBritish Entente took shape, confirming Bibesco's strategic projection and correct reasoning. His personal amity with three of the Ministries of Foreign Affairs of Romania (Alexandru, Ioan and Iacob Lahovary, all Francophiles) was a collaborative one, with reciprocated appreciation based on the common perception of the need to engage Romania's foreign policy closer to Paris, London

\footnotetext{
${ }^{30}$ A Hohenzollern on the throne in Bucharest was not compatible with the interests if France, nor Russia, nor AustriaHungary, who saw the new young monarch as an extension of Prussia's interests on the Danube.

${ }^{31}$ His opposition was not directed personally or especially against Karl I of Hohenzollern-Sigmaringen, but against the principle of a ruler of foreign origin.
} 
and Sankt-Petersburg ${ }^{32}$. Such a change in direction proved undeniably fruitful and was consecrated by Romania siding with the Entente during the First World War and anchoring it, during the 1920s1930s, in the Anglo-Franco-American sphere of global interests until 1938.

The context proved to be a fertile ground for the Bibesco, Ştirbey and Brancovan descendants, as they were able to contribute, from new positions, to the political, military and economic interests of the country. This is what enables the analysis of their activity from the perspective of the evolution of diplomatic practices after the First World War, both in terms of continuity and of innovation coming with the new institutional architecture of the League of Nations and with the intense global interaction of its members. In this context, a study should therefore consider the emergence of non-state actors, first and foremost individuals involved in the process - with traditions and procedures already established, engaging their personal credibility in formulating and expressing the official position of their nation -, next to private or institutional networks in use for the transmission of diplomatic messages (Bjola, Murray, 2016; Boisard, Chossudovsky, 1998; Badel, 2007; Tenzer, Devin, Badel, Pierre, Lefebvre, 2012).

The geographic dimension of post-1920 diplomatic interaction was also changed: one shall have to considered it with its multiple directions, in regional terms (the Little Entente, the Balkan Pact), interregional (defined by interaction with third parties themselves included in other regional arrangements, i.e. Poland), as well as European or international (through the League of Nations). All generated a rather atypical architecture between bilateralism and multilateralism. Within it, one must follow the diplomatic praxis of non-diplomatic actors because, in the dynamic of this new interaction, one can notice a transition from diplomacy - understood institutionally as a tutor of the international relations system (White, 1978) -, to diplomacy understood as a conduct and as demeanour, as value and attitude, the diplomat being defined through his profile and his abilities more than through his public office integral to the State institutions. While the international relations historiography tends to validate the rise of non-state actors only for the last 30 years, an investigation into the phenomenon demonstrates that these actors were already existing, exerting diplomatic functions and rivalling or acting complementarily with classic diplomatic actors in

\footnotetext{
${ }^{32}$ George II Bibesco died in May 1902. In 18 years, between March 1889 and March 1907, the three Lahovary brothers led the foreign affairs of the country for almost 10 (1889-1891, 1891-1895, 1899-1900, 1904-1907 (Iordăchiţă, 2004). This tendency also impacted on the choice of an Anglo-Russian bride for the heir of the Romanian throne, Prince Ferdinand de Hohenzollern-Sigmaringen.
} 
areas like State representation, intelligence or negotiations (Armstrong, Bello, Gilson, Spini, 2010).

The 1900s-1940s already saw the integration in the diplomatic milieus of experts coming from the private sector (such as bankers and captains of industry), the academia or various ministries (military officers, economists, financiers); what the $20^{\text {th }}$ century will bring is the progressive institutionalisation of cooperation between public, para-public, private actors and international organisations, as demonstrated by article 71 of the UN Chart (that allows limited participation of NGOs to UN's activities via consultations) or the recognition, in 2003, by the Council of Europe, of the participative role of the NGOs in international relations (Rana, Kurbalija, Katrandjiev, 2006).

But today's question is whether one can talk about a diplomacy uninfluenced by the political sphere in its directions or patterns, a diplomacy which would be largely private. The economic diplomacy of entrepreneurial networks, the corporate one or the one of private institutes of research, of think-tanks and foundations already give a positive answer. Their present definition pertains to a few factors; the NGOs and corporations, for instance, develop internal communication structures, dedicated to international or institutional relations, and which manage - with personnel and recruits of diplomatic background - their non-material assets: the public image, the brand, the reputation. This is a praxis largely related to maximising benefits in the "global village" and responds to civil society's exigence with regard to criteria of sustainability and responsibility.

But such methods were already in place at the end of the $19^{\text {th }}$ century, set up by the large companies of the time (Badel, 2006), and the question that has to be asked - in order to differentiate between the two - relates to the degree of emancipation from the State, to the national or territorial course of their action, because the dimensions and the omnipresence of corporations enable political scientists to talk about "private multilateralism" (Bull, McNeill, 2007; Harvie, Kimura, Lee, 2005; Schechter, 2016). We witness an economic diplomacy assisting the country brand, betting on the alliance between national interests and of the nation's leading economic players, with the diplomatic service supporting corporations in order to give credit to strategic investments. In the 1900s-1940s, economic partnership and State-owned or private companies proved to be genuine vectors of official diplomacy; in Romania, this role was played by petroleum businesses, some of the steel producers and a few powerful banks. 
Last but not least, it must be underlined that private actors benefit from the transformation of the cultural diplomacy into a diplomacy of influence, bringing together a classic initiative of the cultural diplomacy (itself transformational because of the transfer of knowledge and know-how it implies) with new practices, destined for a specific audience, with a certain degree of reciprocity and focused on the public image a country acquires ${ }^{33}$. The actors involved in this sphere are predominantly literati, perceptive and insightful, genuine connoisseurs, with an ability to relate to other societies in a degree that includes significant cultural affinity.

One by one, a few characters from the three abovementioned Romanian families match these categories, which they illustrate individually.

\section{Antoine Bibesco. The Diplomat}

Son of Alexandre Bibesco, Antoine (1878-1951) is remembered today for being an inspiring friend of France's most magnificent writer, Marcel Proust. He and his brother, Emmanuel Bibesco, introduced Proust to Bergson's theories, to Ruskin's works, to Diaghilev's ballet and to the French gothic art, while Antoine is additionally known to have been a model for Saint-Loup, a main character of $A$ la recherche du temps perdu (Painter, 1966, 1992; Tadié, 1996, 2000; Diesbach, 1991, 1999; Bibesco, 1928). (In addition, just like their uncle George II with Renoir, the two brothers were also discreet and generous benefactors of painters Gauguin and Vuillard.) Born in France, Antoine Bibesco studied in Britain, at Canterbury, before joining the diplomatic service of Romania in 1899 as embassy secretary in London (AMFAR, 77; BAP, 27).

In 1917, he was appointed in Washington DC. Yet, because of the war, he was not able to fulfil his duties and reached the US capital only in 1920 (AMFAR, I, 107; NYT, 1920, 1921). In the meanwhile, his personal situation has changed significantly. He had married Elizabeth Asquith, daughter of Henry Herbert Asquith - the Liberal Prime Minister of Great Britain - by Margot Tennant, one of the central figures of literary and social London. Elizabeth's glittering social circle

\footnotetext{
${ }^{33}$ Best illustrated most recently by the "mask" or "vaccine diplomacy" during the SARS-CoVid19 pandemic of 20202021.
} 
extended to the fashionable sets The Coterie and The Bright Young People ${ }^{34}$, as well as the British royal family ${ }^{35}$. Elizabeth was a writer herself ${ }^{36}$. When in Washington, she easily befriended Franklin Delano Roosevelt, starting a 25-years long amity that would end only with their death (Bibesco Archives, 2).

Antoine and Elizabeth operated as a diplomatic and cultural couple. His personal connections, such as the one to Bernard Baruch (financier and advisor to US Presidents Woodrow Wilson and Roosevelt), facilitated Romania's negotiations for a state loan much needed after the war $^{37}$. It also helped into reassuring the Jewish-American community that the new Romania was going offer citizenship and minority rights to the Jews, which the government effectively enshrined in the new 1923 Constitution (AMFAR, Bibescu-Baruch).

In addition - with their cultural reputation well-established in Paris and London -, the receptions and soirées hosted by the two Bibesco turned the Romanian Legation into an attractive social spot in Washington DC.

Antoine's success in London and Washington displeased Nicolae Titulesco - the eminent Romanian diplomat, Minister of Foreign Affairs, twice President of the General Assembly of the League of Nations (1930-32) -, who repeatedly attempted to have Antoine Bibesco dismissed. The dispute, started by Titulesco and taken very personally, oscillated between confrontation and

\footnotetext{
${ }^{34}$ The Coterie reunited sons and daughters of British politicians and businessmen, such as Lady Diana Manners (daughter of the $8^{\text {th }}$ Duke of Rutland, herself an elected politician and influential socialite); her husband, Alfred Duff Cooper (Conservative politician and diplomat, friend of Stanley Baldwin and of Winston Churchill - both future Prime Ministers -, Ambassador to France from 1944 to 1948); Raymond Asquith, son of the Prime Minister, politician and barrister (Elizabeth's half-brother); Maurice Baring (of the Baring banking family); Nancy Cunard (political activist and literary socialite, Anglo-American heiress of the Cunard fortune), etc. The Bright Young People were a group of wealthy, bohemian young aristocrats and socialites in 1920s London, including Harold Acton, Patrick Balfour, Bryan Guinness (of the Guinness family), the five Mitford Sisters, the Sitwells, artists like Cecil Beaton and writers like Evelyn Waugh (Mackenzie, 1986; Lambert, 1984).

${ }^{35}$ Antoine and Elizabeth's daughter Priscilla (1920-2004) was the goddaughter of Queen Alexandra of Great-Britain and Ireland (regn. 1901-1910) and of writer Marcel Proust. Winston Churchill was a close friend of Elizabeth's elder half-sister, Violet (Asquith) Bonham-Carter (1887-1969), herself a politician, diarist and devoted supporter of the European integration as well as of the United Nations (Pottle, 2007).

${ }^{36}$ Author of I Have Only Myself to Blame (1921), Balloons (1922), The Painted Swan (1922), The Fir and the Palm (1924), The Whole Story (1925), There is No Return (1927), Points of View (1927), Poems (1927), Portrait of Caroline (1931), The Romantic (1940).

${ }^{37}$ This was included in the larger frame of post-war financial compensations and debt negotiations (Dimineata, 1925; Berea, 1925; The Times, 1925).
} 
concession, but it would end only in 1936, when the minister - removed from all official positions - was asked by King Carol II to leave the country and never return ${ }^{38}$.

The next appointment, in Madrid, is probably the best example of collaboration between the networks of the two. Antoine was acquainted with King Alfonso XIII; Elizabeth was a friend of Queen Eugenia - of German-British origins -, and this gave the couple a position de faveur at the Spanish Court (BAP, 2). While Antoine was representing Romania's political interests and stood away from conflicting political ideologies (including after the Republican shift of 1931), Elizabeth was receiving, socially, both the Spanish Liberals (Madariaga, Manuel Azaña, Gregorio Marañón) and their rival, José Antonio Primo de Rivera (Azaña, 1961, 1981; Bowers, 1954). It was to her that Rivera wrote one of his last letters before being executed, praising her fairness and spirit of justice (Thomas, 1961; BAP, 2). She had tried to save him from his fate in the same way

\footnotetext{
${ }^{38}$ The controversial private personality of Nicolae Titulescu is rarely subject to academic studies, as it is considered to be damaging to the image of one of Romania's leading diplomats. Yet, 80 years after his death, for the sake of objectivity as well as for understanding why some of his plans and negotiations collapsed, it is necessary to describe and analyse Titulesco's private profile featuring tremendous ambition, concern for visibility and for a manicured public image, mixing victim-playing, self-righteousness and a profound detestation of any possible competitor. His appetite for luxury, for approval and reputation, his lack of control, his controversial political activity, intrigues, double standards and personal rivalries - though underlined by his contemporaries (such as Nicolae Iorga, prominent historian of European fame and Prime Minister of Romania) - were delicately put aside by Romanian historian (Macri, 1992). In 15 years of activity, Titulescu managed to become the enemy of all political parties in power, not to mention of major statesmen and politicians: King Carol II, G. Tataresco (twice Prime-Minister, thrice Minister of Foreign Affairs), I. Inculeţ (deputy Prime-Minister, Minister of Internal Affairs), V. Antonesco (Finance Minister, Minister of Foreign Affairs), R. Franasovici (diplomat, Ambassador in Poland and Switzerland, Minister of Internal Affairs), V.V. Tillea (Minister of Romania in London), G. Gafencu (Minister of Foreign Affairs, Ambassador to Moscow, member of the European Movement after 1948), C. Argetoianu (Finance Minister, Minister of Internal Affairs, Minister of Agriculture, etc, Prime-Minister), G. I. Brătianu (Liberal leader, professor), etc... (Potra, 2013). The conflict with Antoine Bibesco started when Titulesco, appointed to London as minister of Romania in 1924, noticed that he is largely ignored by the British establishment; he lacked the social connections Antoine Bibesco disposed of. Outraged, he initiated in Paris and London a vilification campaign against Bibesco, who easily found out through a common friend, senator and minister Henry de Jouvenel. In the United States, during the Washington Financial Conference, Titulescu - who was heading the Romanian negotiation delegation - attempted to exclude Bibesco from it, despite Bibesco's official position. The Ministry of Foreign Affairs forbade him to, but the interdiction infuriated Titulescu even more: he started a new denigration campaign against Bibesco in front of the American State administration and financiers. Antoine was aware of it, yet dismissive of Titulesco's unsuccessful attempts, as his letters to N. Iorga demonstrate (BAR, Manuscripts). It was only in 1927 that Antoine's cousin, Marthe Bibesco, could mediate a temporary 'truce' between the two, sealed with the designation of Antoine as ambassador of Romania to Madrid. By mid-1930s Titulesco was perceived, both by King Carol II and the political milieus, as clearly trying to leverage his influence in Romanian politics by using his personal amity with various ministers of foreign affairs, especially Maxim Litvinov (USSR), in order to stay in power and become the arbiter of Central and Eastern Europe. King Carol II, who resented Titulesco fondness for taking decisions without consulting the Crown (himself with appetite for unquestioned authority), took advantage of his minister's multiple errors in relation to Germany, Italy, Spain and Poland, and asked for his resignation. But the rivalry with Bibesco did not end; after Titulesco's downfall, Antoine would serenely contribute to King Carol II's plan of making sure that the former minister was not going to recover his credibility in London and Paris...
} 
she tried to help the French ambassador in Rome, Chambrun, about to be discharged by Léon Blum, Prime Minister of France and friend of Antoine, because he failed to convince Mussolini not to support the Spanish Fascists (Greilsammer, 1996) ${ }^{39}$. Unfortunately, she did not succeed.

Elizabeth died in 1945, a few days before the Communists seized power in Romania. Antoine had to flee the country in the same year. He went to Paris, where he used his personal connections in the British diplomacy (Duff Cooper, the ambassador ${ }^{40}$, and Harold Nicolson) to have access to the American circles discussing Europe's future. His objective was to intervene in ways that could serve Romania's interest: that is to be recognised as co-belligerent of the United Nations, and not condemned as ally of Germany; to preserve as much as possible the frontiers of 1940, if not 1938; and to see that the country stays independent ${ }^{41}$. In this, Duff Cooper had proved to be an unexpectedly close ally ${ }^{42}$, even if - in the end - the outcome of the Second World War proved to be, for Romania, the worst in its entire modern history.

\section{George III Bibesco. The Pragmatic}

George III Valentin, $4^{\text {th }}$ Prince Bibesco (1880-1941), son of George II Bibesco by Valentine de Caraman Chimay, of the Belgian princely family, was by all definitions a sportsman. Impetuous, daring, intrepid, his audacity - when touring Europe, the Middle East, Africa and India by car and planes - bordered heroism. He became president of the Romanian Royal Air Club and

\footnotetext{
${ }^{39}$ The amity between the two Bibesco brothers, Emmanuel and Antoine, with Léon Blum had started in the late 1890s or the early 1900s. The friendship with the Chambruns was already entering the $3^{\text {rd }}$ generation (BAP, 2).

${ }^{40}$ Not only friend of Churchill, but of Cynthia Asquith as well, Elizabeth's sister-in-law, whom Duff Cooper had appointed as director of War propaganda when he was Minister of Information under Churchill (1940-1941). (As a genealogical amusement - yet demonstrating the continuation of the networks of power -, Alfred Duff Cooper is also the great-uncle of Great Britain's Prime-Minister David Cameron, descended on his paternal line from Cooper's sister Stephanie.)

${ }^{41}$ Memoirs of Herbert Zilber (1901-1978), early Marxist Romanian politician co-opted by the Communist government, member of Romania's delegation to the Paris Peace Conference of 1946; disenchanted with Communism, he was accused of treason and jailed from 1947 to 1963. "I have no idea how [Bibesco] was managing it, but every time I had to meet one of the delegates [of Britain and the USA], they were already warned about my requests by Bibesco, who was somehow meeting them before I could" (Ioanid, 1992).

${ }^{42}$ Facilitating (next to John and Allan Foster Dulles) Bibesco's access in the Luxembourg Palace, where the Peace Conference was taking place, or (apparently) taking into consideration the observations issued by the representatives of the Romanian democratic parties (who published their arguments in the 147-pages book La Romanie devant la Conférence de la paix de Paris, Bern, 1946). For Antoine's private visits at the British Embassy in Paris: Cooper, 1981.
} 
embarked on an international career that was to bring him the presidency of the World Air Federation ${ }^{43}$.

The World Air Federation played a political a role in the 1920s and the 1930s that was never replicated ever since. Created in 1905 by Prince Roland Bonaparte, it gradually became not only an institution dedicated to air sports and world records, but a platform reuniting the Ministries of Air or Aviation ${ }^{44}$ from different European countries and the United States. It consisted of almost 40 air clubs, with diplomatic, strategic and military potential, as most of the national delegates had political or military ranking and were connected to the aircraft manufacturers of their countries (such as Blériot, Potez ${ }^{45}$, Zodiac, Fokker, Vickers, Rolls-Royce, Fiat, Hispano-Suiza, etc.). The decisions taken were often politically influenced (Pépin, 1968). George III Bibesco's election as president in 1930 - surprisingly against the French candidate - succeeded because of the support of Germany, Austria, Hungary (who had lost the war), but also of Czechoslovakia, Yugoslavia and Poland, Romania's allies in the Little Entente (AMNA, II).

Reforming the institution was certainly on George Bibesco's agenda: (1) first, by transforming it into a respected international institution regulating world's commercial aviation, as airliners, seaplanes and airships were demonstrably more profitable than railways and Atlantic liners; (2) second, exploring and opening new air ways to connect European countries (increasing the sense of European unity), as well as metropoles to their colonial empires; (3) third, facilitating air travel ${ }^{46}$. For Bibesco, airspace was a source of prosperity and, because of it, a source of mature reconciliation between nations. This is why reconciling France, Germany and Italy stood high on his agenda, next to developing aeronautics in a South-Eastern Europe that was so close to the Anglo-French interests.

\footnotetext{
${ }^{43}$ Fédération Aéronautique Internationale (fr.), World Aeronautical Federation (engl.), acronym F.A.I., headquartered in Lausanne, Switzerland.

${ }^{44}$ Such ministries included the civil and the military aviation administration.

${ }^{45}$ Whose director before the 1936 nationalisation was Abel-François Chirac (1898-1968), father of Jacques Chirac, French Prime-Minister (1974-1976) and President (1995-2002-2007).

${ }^{46}$ In 10 years of presidency, George III Bibesco transformed profoundly global aviation. Until 1936, his achievements were the following: regulation of tourist passports, reduction and harmonisation of airport taxes, reduction of the number of no-flight areas, introduction of special regulations for the Red Cross planes, free passes for sporting pilots, permission to install telegraphs in airports, permission for pilots to unrestrictedly use the airplane's radio stations in order to communicate, etc. (Aripi, 1931a, 1931b; România aeriană, 1931; AMNA, GVB, II).
} 
Bibesco did not ignore the military aspects of the WAF. Strong Romanian, Yugoslavian and Greek aviation would have contributed to Europe's peace by diminishing the aggressive attitudes of a few vindictive neighbours, especially the Soviet Union. In this, the strategic national interests of the Little Entente and the policies of the WAF strongly coincided (AMNA, IIb).

"A new era of harmony and understanding" had to begin, Bibesco considered (Aripi, 1931). Under the leadership of so many political personalities (Aripi, 1932) and "preparing for peace, civil aviation [should] become the very soul of international exchange in all fields" (AMNA, I). Consequently, he decided to create a permanent Council of the WAF and, together with Italy's Minister of Air, Italo Balbo, to create a permanent office of the WAF to the League of Nations, gathering air clubs and affiliated associations which dealt with air jurisdiction, commercial and leisure travel. Germany immediately supported the initiative.

However, George Bibesco was worried by the League's incapacity to guarantee collective security. Through his wife Marthe - the celebrated writer-, he invited Louise Weiss to Mogoşoaia. Weiss, French journalist and politician, was an activist for peace, founder of the Europe Nouvelle magazine, pleading for reconciliation between France and Germany. She was surrounded by brilliant intellectual names, such as Henry de Jouvenel, Wladimir d'Ormesson - future ambassador of France in Romania, just like his brother André d'Ormesson ${ }^{47}$-, Aristide Briand, Édouard Herriot, Léon Blum, Saint-John Perse, Paul Valéry, Élie Faure (most of them already friends of George's wife, Marthe, née Lahovary). But Louise Weiss was also a relative of Lazare Weiller, French industrialist whose son, Paul-Louis Weiller - himself a social friend of the Bibescos - had married a princess Ghika, cousin of Bibesco. To Weiss, he wanted « to demonstrate the stupidity of a peace with no means of preservation, all the decisions, convictions, judgments and decrees falling into the void. He wanted the establishment of an International Air Force, a coalition, the only gendarmerie possible. It was a beautiful dream », Marthe Bibesco wrote to an Italian correspondent in 1970 (BAP, 21). Indeed it was, and George Bibesco had considered it since 1932: a world air-force carrying out the peace-keeping mandate of the League of Nations. (RAI, 1933)

But his hopes were challenged by both Nazi Germany and Fascist Italy.

\footnotetext{
${ }^{47}$ Father of celebrated French writer and member of the Institut de France, Jean d'Ormesson (1925-2017), who spend a part of his childhood in Romania.
} 
While the British government's position towards WAF was rather ambivalent, the British Under-Secretary of State for Air, Sir Philip Sassoon (a member of the Sassoon and Rothschild families) was a cooperative friend. It was to him, in private, during a visit to Port Lympne in 1933, that George Bibesco suggested a reinforcement of Britain's coastal aerial defence, as the German aviation was about to become the most powerful in Europe (Sandachi, Hadîrcă, 2005). It was the same warning that he later addressed to Lord Londonderry, Secretary of State for Air during MacDonald's government, and second cousin of Winston Churchill (Le Moment, 1936).

After 1936 and the Second Italo-Abyssinian war, in a more and more confrontational Europe, it was difficult for Bibesco to impose his views on the peaceful use of airplanes. His last success, in December 1939, during the Switzerland congress of the WAF, was to offer the federation's services to the International Red Cross - a proposal unanimously accepted now that diplomacy had been replaced by warfare (Aérophile, 1940).

\section{Constantine de Brancovan. For a New Diplomacy}

Constantine, $8^{\text {th }}$ Prince de Brancovan (1875-1967) is less known than his illustrious sister, Anna, Countess de Noailles, Parnassian poetess, friend of the French intellectuals of the BelleÉpoque and member of the Royal Academy of Belgium for French Language and Literature (Higonnet-Dugua, 2000; Nantet, 2014). Twice a prince, sophisticated socialite, main heir to the rights of the ancient national dynasty - yet born and raised in France -, Brancovan was one of the wealthiest individuals in Romania, the largest landowner in the country, a social-liberal with a touch of conservatism, custodian of the oldest private philanthropic foundation and owner of archives that reputed historians enjoyed exploring.

Because most of his social and cultural interests were in France, while his patrimony was located in Romania, he moved constantly between Paris and Bucharest. He chose to be an advocate of his country (Iorga, 1934, 1984), in what we call today cultural diplomacy. He founded the Renaissance Latine magazine ${ }^{48}$, destined to revive the interest of the French public and political élite for other Romance-speaking nations in Europe and the Americas, with a focus on Romania

\footnotetext{
48 On Gallica at [http://gallica.bnf.fr/ark:/12148/cb344304292/date] (accessed on May 20, 2020). His young friend, Marcel Proust, was among the magazine's authors, next to Pierre Loti or Franz Funck-Brentano.
} 
(indisputably the most Francophile country in Europe at that time) ${ }^{49}$. The magazine was dually structured, in order to discuss not only the most recent developments in the economy, society, culture and politics of the Latin nations of Europe, but also themes of interest (the Dreyfus affair, European socialism, the Armenian question...). In doing so, he was promoting Romania as a young, dynamic and transformational country, friendly to France, constant and committed to Europe's best interests, but also culturally mature and productive. But the magazine did not survive more than three years, and Brancovan returned to his political interests. He was initially close to the Liberal party, and rather in favour of a Social-Liberal approach inspired to him by the French solidarisme of Léon Bourgeois (Brancovan, 1905).

After assuming a few paradiplomatic missions during the First World War, especially in negotiating a common Romanian-Italian position in 1915 with respect to their neutrality - or not - (Argetoianu, 1991), his interests converted to industry and finance after 1919. He became shareholder and president of different banking, mining and petroleum corporations created with French and Belgian capital (Sturdza, 2011) $)^{50}$. But he did not neglect his diplomatic concerns. He was a member of the Académie Diplomatique Internationale (AADI, 2013) in Paris, which, along with Chatham House in London and the Council on Foreign Relations in New York, was one of the first institutions devoted to the study and analysis of international relations. Aristide Briand, Eduard Benes, Gustav Stresemann, F. D. Roosevelt were among his titular confrères and he attended as often as possible meetings concerning the codification of international law, minorities

\footnotetext{
${ }^{49}$ Cultural magazines of this kind were frequent in the late 1890s and the early 1900s. Polish prince André Poniatowski financed the "Revue franco-américaine" (1895); the following "Revue franco-anglaise" (1895-1898), "Revue francohollandaise, artistique et littéraire" (1896-1897), "Cosmopolis" (1896-1898), "Revue franco-hongroise" (1900), "Revue franco-persanne" (1901-1902, financed by the Persian Shah himself), "Revue franco-musulmane" (1902), "Nouvelle Revue Européenne" (1897), "Revue franco-allemande", "Revue franco-autrichienne" (1909-1910) did not survive for more than three years - nor did the "Revue internationale illustrée; organe politique, littéraire, mondain et financier" launched immediately afterwards in 1910. The "Revue franco-roumaine" failed as well in 1901.

${ }^{50}$ Such as 'Banca Comercială Română', Romania's largest, recreated as a joint-venture with La Banque Belge pour l'Etranger and La Banque d'Anvers, with strong investments in the aircraft industry, energy and luxury (Coty); or 'Concordia Petroleum', re-established as an investment of the Compagnie Financière Belge des Pétroles (Petrofina, via the Société Commerciale Belge des Pétroles). - His connections to Belgium were strengthened by his sister's marriage into the Chimay family: Hélène Bibesco Bassaraba de Brancovan (1878-1929) was the wife of prince Alexandre de Caraman-Chimay (1873-1951). Alexandre himself would be the uncle of Michel Poniatowski (19222002), better known as "Ponia", longtime friend of Valéry Giscard d'Estaing, French politician, co-founder of the Independent Republicans, Minister of Health (1973-1974), Minister of the Interior (1974-1977) during Giscard's presidency in France, founder and honorary president of the Union pour la Démocratie Française, UDF.
} 
in Europe, the International Court of Justice, the organisation of peace by the League of Nations, the Briand-Kellogg pact, etc.

In these milieus he met André Chéradame (1871-1948), French journalist and scholar from the Sciences Politiques known for his articles, interventions and books on the geopolitics of Europe. Chéradame was concerned especially by Germany's expansion and militarism, and denounced the involvement of the German General Staff in plans aiming to create a Greater Germany that would first engulf Central-Eastern Europe, then all of Europe (Motte, 2008; Ginsburger, 2014). Churchill sometimes shared the same idea. Dismantling the German territory, the German institutions and their military elite, rejecting the Franco-German reconciliation and the international financial aid for Germany were, for Chéradame, the only possibility to preserve Europe's peace. Brancovan did not have the same views, but in the early 1930s he helped Chéradame organise a conference tour in Romania (Gafencu, 1991) where the French scholar expressed his opinions on the containment of Germany - needed after 1933 -, and accused France and Europe for their lack of boldness in confronting what obviously was Germany's policy to dominate the continent ${ }^{51}$.

More discreet than his cousins, and leaving behind less traces of his activity ${ }^{52}$, Brancovan is nevertheless innovative when deciding to use his business network in order to amplify economic collaboration, and increase the degree of interdependence between the advanced European economies and the growing East, anchoring one to the other especially in the strategic field of oil extraction, at a time when Romania was a still substantial player. For him, peace could be built on reasonable economic partnerships: after all, "les bons comptes font les bons amis".

\section{Barbo Stirbey. The Negotiator}

Born in 1872, Barbo, third Prince Stirbey, was a statesman, a prosperous businessman, former administrator of the Crown Estates, Minister of Finance, of Foreign Affairs, Prime Minister and member of the Romanian Academy. Charismatic, tactful, judicious, calculated, married to a Bibesco cousin, he was involved in a discreet way in the Romanian politics, as royal adviser and

\footnotetext{
${ }^{51}$ A support committee in favour of maintaining the European treaties in vigour was created by Chéradame in Central Europe. The Romanian one was presided by Constantine de Brancovan who had coopted high ranking politicians, senators, ministers and diplomats (of which two Romanian members of the Académie Diplomatique Internationale)(Gafencu, 1991).

${ }^{52}$ Much of his private archives were lost, confiscated by the Communist authorities in 1948.
} 
brother-in-law of Liberal Prime Minister Ion I. C. Brătianu. The most dramatic episode of his political life took place during the Second World War, when he would become involved in Romania's negotiations with the Allies. Assuming such a role was compatible to one of Ştirbey's most profound convictions: to be a constant representative of Great Britain's interests on the Danube (as London was the political capital of the Anglo-American sphere after the First World War) and to work for the inclusion of Romania in the British Empire's global strategy; in other words, giving Romania the role of valuable ally of Great Britain and of the United States ${ }^{53}$.

As Nazi Germany's was confronted with immense losses in Russia and it became obvious that they cannot win, Romania considered negotiating since 1943 its way out of the war (Puşcaş, 2003). In 1942 the American government informed Romania, through private channels ${ }^{54}$, that withdrawing the armies from the Soviet territory behind the frontier-lines of 1940 is acceptable and understandable - but advancing would be a strategic mistake. One year later, Marshall Antonescu, the Ministry of Foreign Affairs and the leaders of the Democratic opposition (Iuliu Maniu, Dinu Brătianu) joined their efforts and sent various messages to London, Washington and Moscow both officially and in private. Yet, very aware of the unnatural alliance between the Anglo-Saxon powers and the USSR, Romania hesitated; for historical reasons - twelve Russian invasions in 150 years, long military occupations and land annexations -, the country's diplomatic agents preferred negotiating only with Great Britain and the USA, not with Soviet Russia. What Romania was asking for, in 1943, were British and American guarantees for the country's frontiers, and a fair truce treaty. If Romania was to negotiate with the Soviets, that had to be done only with an Anglo-American undertaking or their formal assurance. In the same time, Antonescu had started negotiations with Mussolini so that Romania, Italy and other Axis allies would withdraw from the German alliance, forcing Hitler to start talks with the British and the Americans (Baciu, 1988).

Romania's initiative met Britain's own attempt to detach Romania and Bulgaria from the German alliance. Britain had almost accepted the idea of a territorial guarantee offered to Romania,

\footnotetext{
${ }^{53}$ It is from this point of view that his contact with British industrial corporations has to be understood (as president of Uzinele Reşiţa he was a collaborator of Vickers-Armstrong and of Nobel Industries, later Imperial Chemical Industries)(Teichova, Lévy-Leboyer, Nussbaum, 2002; Davenport-Hines, 2013; Deletant, 2016); this would bring a certain convergence with the British intelligence. To these one must add Barbo Stirbey's support for the creation of a British military base at the Black Sea (Cîrstea, 2013).

${ }^{54}$ Private meeting in Bern of Marthe, Princess Bibesco with Leland B. Harrison, US Ambassador to Switzerland (former US minister to Romania), see Bibesco, 1957.
} 
but the US hesitated, as political views in Washington and military decisions on the field were not always compatible. It was in these circumstances that Prince Stirbey (using the codename 'Bond') was allowed to go to Ankara and Cairo, to negotiate with the Allies the decoupling from Germany. Firstly, because he was a skilled negotiator; aecondly, he was at the centre of an intelligence network that offered him both the means and the credibility to negotiate ${ }^{55}$.

In March 1944, he was to meet British diplomats in Ankara (Petersen, 2010); he expressed support for Marthe Bibesco's suggestion to create an Eastern European Federation based on the former Little Entente, Poland and Greece (Diesbach, 1998), a project that partly superposed Churchill's idea of a Danube federation (Potsdam, 330). Later, in Cairo, he delivered Romania's proposition: a military U-turn against Germany if Romania receives guarantees of post-war territorial integrity and independence. The Americans initially agreed, and went as far as offering Romania the status of co-belligerent. But parallel talks were held through the Soviet embassy in Stockholm by the Romanian government, with little efficiency, and time was running out. As the Soviet armies drew closer to Romania, the Allies were increasingly asking for the country's unconditioned surrender - a proposal considered unacceptable by both Antonescu and the democratic opposition, which brought a new round of talks. As the Anglo-Americans were already focusing on the Normandy landing, they asked Romania to negotiate now with the Soviets and to treat them as equal partners of Britain and the USA within The United Nations. Or, the first reaction of Soviet Russia was to demand recognition of the July 1940 frontiers, consecrating the loss of Bessarabia and of northern Bukovina, next to a series of exorbitant territorial and political demands (Petersen, 2010).

In addition, Stirbey assumed a risk by going to Cairo. In spite of this, his mission, supposedly secret, has been publicly unmasked (Puşcaş, 2003; Baciu, 1988; Petersen, 2010). The origins of the leak are still debated and concern possible agents from Bucharest, ambitious politicians unwilling to see the truce with the Allies signed by Marshall Antonescu or the British themselves, in an attempt to determine a German invasion of Romania and thus reduce the number of Wehrmacht soldiers fighting in the West. The debate extends to whether it was genuine leak or

\footnotetext{
${ }^{55}$ Of his four daughters, one has married John Boxshall, collaborator of the MI6 office for Romania; another one was the wife of Alexandru Cretzianu, ambassador in Turkey, and a third was the spouse of a State official, head of the Cipher Bureau.
} 
if it was Stirbey himself who blew the whistle, in a plan agreed with the British, meant to distract the Germans in the East, so that the Normandy landing could be meticulously prepared.

In 1945, the young King Michael of Romania thought of appointing Stirbey Prime-Minister and head of a grand coalition government including representatives of the Communist party. It was a strategy of appeasement and an attempt to diminish the Soviet influence in the country. In addition, Stirbey's British connections were vital in balancing Moscow's political pressure. Foreseeably, the Soviets opposed and imposed Groza, their own political tool. Vyshinski, former Soviet State prosecutor and minister of foreign affairs, deliberately came to Romania in early March 1946 to make sure opposition is handled properly. Apparently it was. Barbo Stirbey died the next day after attending the Soviet embassy reception he was invited to (Tănase, 2017, 2020).

\section{A few conclusions}

Opening a new direction of research, the article above is merely a fresco of a few Romanian historical figures, meant to illustrate the capacity of certain private individuals to act at international level, based on personally cultivated relations and designed to serve Romania with the intent of keeping the country in a partnership with Western powers, on political and economic ties. The arrangement went back to a creed originating in how the three families' predecessors approached international relations and foreign policy in the $19^{\text {th }}$ century: based on the idea that Romania should develop in a European system built on international treaties, in an international society defined by law, negotiation, mediation and cooperation.

The action line of the three families was asymmetrical and not always concerted, but it covered key areas of diplomatic interaction, not only in politics and economy, but also in culture, international law and diplomacy. It is in this way that the Bibesco, Brancovan and Stirbey families belong to a "European international" created and shaped by historical elites with an undeniable influence in foreign affairs, especially in Europe until late in the 1980s - a topic that needs further, comprehensive exploration.

\section{References}

1. *** Dimineaţa, 1925. România aranjează datoriile de război faţă de America?, July 18. 
2. $* * *$ Foreign News: 55-Year War, 1941. In: Time Magazine, June 30 available at http://content.time.com/time/magazine/article/0,9171,851234,00.html (accessed January 2020)

3. *** L'Aérophile, 1940, January, pp. 24 şi XX

4. *** La Roumanie devant la Conférence de la paix de Paris, 1946. Bucharest: editura Revistei române

5. $\quad * * *$ Le Moment de Bucarest, 1936, October 13

6. $\quad * * *$ New-York Times, 1920, July 29, p. 2

7. $\quad * * *$ New-York Times, 1921, January 30, p. 4.

8. $\quad * * *$ Revue Aéronautique Internationale, 10/December.

9. $\quad * * *$ The Times, 1925. Romania's War Debt to the USA. September 16, p. 12

1. AADI, Archives of the Académie Diplomatique Internationale, Paris, members registry, Romania (46 members); private copy received in 2013, courtesy of Mrs. Shirin Melikoff Sayar (to whom we express full gratitude)

2. AMFAR, Archives of the Ministry of Foreign Affairs of Romania, Bucharest, 77 (Personnel of the Ministry of Foreign Affairs, 1876-1948), Anton Bibescu (personal files), I, f. 107; Diplomatic Correspondence: Bibescu Anton / Baruch Bernard

3. AMNA, Archives of the National Museum of Aviation, Bucharest, George V. Bibescu, II, f. $12,35,39,44,54,55$

10. Argetoianu, C., 1991. Pentru cei de mâine, aminitiri din vremea celor de ieri. Bucharest: Humanitas, p. 145

11. Armstrong, D., Bello, V., Gilson, J., Spini, D., 2010. Civil Society and International Governance: The role of non-state actors in global and regional regulatory frameworks. London: Routledge, 2010

12. Azaña, M., 1961 (1981). Memorias politicas y de Guerra. Barcelona: Grupo Editorial Grijalbo I, p. 445, 496, 578, 608

13. Baciu, N., 1988. Agonia României, 1944-1948. München: J.Dumitru Verlag, pp. 22$36,43,67-70$

14. Badel, L., 2006. Pour une histoire de la diplomatie économique de la France. In: Vingtième Siècle. Revue d'histoire 2/90, pp. 169-185 
15. Badel, L., 2007. Pour une histoire de la diplomatie économique: acteurs, culture, enjeux: rapport de synthèse. Paris: Université Paris 1 Sorbonne

4. BAP, Bibesco Archives Paris, French National Library, NAF 28205, D. 29738, box 2, 21,27

5. BAR, Library of the Romanian Academy, Bucharest, Manuscripts, Correspondence of Nicolae Iorga, vol. CCCXXXIII, p. 392

16. Berea, E., 1925. România la conferința financiară de la Washington [Romania during the Washington Financial Conference]. In Dimineaţa, August 16

17. Bibesco, G. V., 1931, România aeriană. V, 48/October, p. 3

18. Bibesco, G. V., 1931a. Aripi, 5/1 May, p. 7

19. Bibesco, G. V., 1931b Aripi, 16/16 October, pp. 1, 8

20. Bibesco, G., 1888. Politique, religion, duel, Paris: Plon

21. Bibesco, G., 1894. Règne de Bibesco. Paris: Plon

22. Bibesco, M., 1928. Au bal avec Marcel Proust. Paris: Gallimard

23. Bibesco, M., 1957. La vie d'une amitié. Paris: Plon, III, p. 527

24. Bjola, C., Murray S. (2016), Secret Diplomacy: Concepts, Contexts and Cases. London: Routledge

25. Boisard M.A., Chossudovsky E.M. (Lemoine, J.), 1998. La Diplomatie Multilatérale. The Hague-London: Martinus Nijhoff Publishers

26. Bowers, C., 1954. My Mission in Spain. Watching the Rehearsal of World War II. NewYork: Simon \& Schuster, p. 67

27. Brancovan, C. de, 1905. Quatre années de régime libéral en Romanie. In: Renaissance Latine, IV, t. 1 (January-March), pp. 105-117;

28. Bull, B., McNeill D., 2007. Development Issues in Global Governance: Public-Private Partnerships and Market Multilateralism. London: Routledge

29. Cîrstea, M., 2013. Proiecte româno-britanice privind construirea unei baza navale la Marea Neagră. Documente, 1929-1939. Târgovişte: Cetatea de Scaun.

30. Cooper, D., 1958. The Rainbow Comes and Goes. London: Rupert-Hart-Davis

31. Davenport-Hines, R.P.T., 2013. Business in the Age of Depression and War. London: Routledge, p. 284; 
32. Deletant, D., 2016. British Clandestine Activities in Romania during the Second World War. London:Palgrave MacMillan, p. XI)

33. Diesbach, GH. d., 1991. Proust. Paris: Perrin

34. Diesbach, Gh. de, 1998. Prinţesa Bibescu. Ultima orhidee. Bucharest: Vivaldi, II, pp. $762-763$

35. Gafencu, G., 1991. Însemnări politice. Bucharest: Humanitas, pp. 62-63

36. Ginsburger, N., 2014. Le 'danger allemand' par les cartes: André Chéradame et l'émergence d'une cartographie géopolitique de guerre. National Library of Frace, public conference, June 12. Available at http://www.lecfc.fr/new/articles/223-article10.pdf, accessed January 2020

37. Greilsammer, I., 1996. Blum. Paris: Flammarion, p. 109.

38. Harvie, C., Kimura F., Lee H.H., 2005. New East Asian Regionalism: Causes, Progress and Country Perspectives. Cheltenham: Edward Elgar Publishing.

39. Higonnet-Dugua, E., 2000 (1989). Anna de Noailles. Coeur innombrable. Paris: Michel de Maulle

40. Ioanid, I., 1992. Inchisoarea noastră cea de toate zilele. Bucharest: Albatros, III, p. 150.

41. Iordăchiţă, C., 2004. Familia Lahovary. Ascendenţă şi destin politic. Piteşti: Carminis

42. Iorga, N., 1934 (1984). O viaţă de om, aşa cum a fost. Bucharest: Minerva.

43. Lambert A., 1984. Unquiet Souls: The Indian Summer of the British Aristocracy, 18801918. London: Macmillan

44. Mackenzie, J., 1986. The Children of the Souls: A Tragedy of the First World War. London: Chatto

45. Macri, C., 1992. Un mit fals: N. Titulescu. In: Cuvântul românesc, Ottawa

46. Motte, M., 2008. Histoire des idées géopolitiques et géostratégiques. In: Annuaire de l'École pratique des hautes études (EPHE), Section des sciences historiques et philologiques, $\mathrm{n}^{\circ} 139$ [http://ashp.revues.org/486, accessed February 2020]

47. Nantet, M.-V., 2014. Anna de Noailles au bord du lac Léman, s.l.: Bleulefit SAS

48. Painter, G., 1992 (1966). Marcel Proust. Paris: Mercure de France

49. Pépin, E., 1968. Le droit aérien. In: Recueil des cours de l'Académie de droit international de La Haye (1947). The Hague: Martinus Nijhoff, pp. 477-548 
50. Petersen, N.H., 2010. From Hitler's Doorstep: The Wartime Intelligence Reports of Allen Dulles, 1942-1945. University Park: Penn State Press, p. 279.

51. Potra, G., 2013. Intrigues against Nicolae Titulescu. In Buşe, C., Cândea, I., Studii de istorie. Brăila: Istros, II, pp. 303-321

6. Potsdam 330: Foreign Relations of the United States: Diplomatic Papers, The Conference of Berlin (The Potsdam Conference), 1945, Volume I, Document 330, Memorandum by the Assistant to the President's Naval Aide (Elsey), at https://history.state.gov/historicaldocuments/frus1945Berlinv01/d330 (accessed February 2021)

52. Pottle, M., 2007. Carter, (Helen) Violet Bonham, Baroness Asquith of Yarnbury (1887-1969). In Oxford Dictionary of National Biography, online edition (http://dx.doi.org/10.1093/ref:odnb/31961)

53. Puşcaş, V., 2003. Speranţă şi disperare. Negocieri româno-aliate 1943-1944. ClujNapoca: Eikon.

54. Rana, K.S., Kurbalija, J., Katrandjiev, V., 2006. Multistakeholder Diplomacy: Challenges and Opportunities. Malta: Diplo Foundation, pp. 13-33.

55. Schechter, M., 2016. Innovation in Multilateralism. New York: Springer

56. Sturdza, M. D., 2011. Familii boiereşti din Moldova şi Ţara Românească, Bucharest: Simetria, vol. II, art. Brâncoveanu

57. Tadié, J.Y., 2000 (1996). Marcel Proust. Paris: Gallimard

58. Tănase, S., 2020, Barbu Ştirbey, omul secret, available at https://www.steliantanase.ro/barbu-stirbey-omul-secret/ (accessed January 2021)

59. Tănase, S., Vijulie, E., 2017, Dinastia, Bucharest: RAO Istorie, passim.

60. Teichova, A., Lévy-Leboyer, M., Nussbaum, H., 2002. Historical Studies in International Corporate Business, Cambridge: Cambridge University Press, p. 133;

61. Tenzer, N., Devin, G., Badel, L., Pierre C., Lefebvre M., 2012. Enjeux et vecteurs de la diplomatie d'influence. Paris: Grasset \& Fasquelle

62. Thomas, H., 1961. The Spanish Civil War. New-York: HarperCollins, p. 352

63. White, M., 1978. Power Politics, New-York: Holmes \& Meyer

64. Ziegler, P., 1981. Diana Cooper. London: Hamish-Hamilton 